\title{
Space Formation of Jaipur City, Rajastan, India An Analysis on City Maps (1925-28) made by Survey of India
}

\author{
Shuji Funo ${ }^{1}$, Naohiko Yamamoto ${ }^{2}$ and Mohan Pant ${ }^{3}$ \\ ${ }^{1}$ Associate Professor, Department of Architecture and Environmental Design, Kyoto University \\ Yosidahonmachi, Sakyo-ku, Kyoto 606-8501 Japan (funo@archi.kyoto-u.ac.jp) \\ ${ }^{2}$ Doctoral candidate, Department of Architecture and Environmental Design, Kyoto University \\ (at.yamamoto@archi.kyoto-u.ac.jp) \\ ${ }^{3}$ Doctoral candidate, Department of Architecture and Environmental Design, Kyoto University \\ (at.pant@archi.kyoto-u.ac.jp)
}

\begin{abstract}
The purpose of this paper is to study the principles of space formation of Jaipur City which is known as the so called grid iron city. Jaipur City, designed by Jai Singh II is thought to have been constructed according to Hindu cosmology. This paper discusses the planning theory in terms of measurement systems employed in the widths and lengths of streets, division of the urban blocks (chowkri) and the distribution of the dwelling units through the analysis of 43 sheets of the City Map (1925-28). The reason why we chose Jaipur is to compare it with Cakranegara (Lombok, Indonesia), which was founded as a colonial city of the Balinese Hindu kingdom in the same period of the early 18 th century.

This paper makes clear that in reality the sizes of the urban blocks are different place by place while simple measurement systems were introduced in the beginning. It also shows the process of city development with respect to changes in the form of the street pattern. The latter part of the paper focuses on the form of neighbourhood structures and, on types of residential buildings that are the cellular units of the residential quarters.
\end{abstract}

Keywords: Jaipur; grid pattern; Hindu city; streets system; haveli

\section{Introduction}

This paper will analyze the block pattern, street system, residential forms and neighborhood structure in the old city area of Jaipur - the capital city of the state of Rajasthan, India.

Jaipur with its streets firmly laid out in a grid pattern is well known as a fine example of a planned city in India. It is considered that the basic concepts are derived from and based on Hindu city planning ideals. This study will finally serve the purpose of comparing the city of Jaipur with Cakranegara, ${ }^{1}$ Indonesia.

Jaipur $^{2}$ was planned according to Maharaja Jai Singh II (1688-1743) $)^{3}$ who was not only a progressive politician and warrior but also an astronomer and mathematician. The principal architect was the Bengali Brahman-Vidyadhar ${ }^{4}$. The basic framework of the city is considered to have been completed by the first half of 18 th century ${ }^{5}$.This was also the period when Cakranegara was built as a colonial town by the king of Karangasem, Bali. That the two cities, one at the east end and the other at the west end of the Hindu cultural sphere, were

Contact Author: Shuji Funo, Dept. of Architecture and Environmental Design, Kyoto Univ., Yosidahonmachi, Sakyo-ku, Kyoto 606-8501 Japan

Tel: +81-75-753-5776 Fax: +81-75-753-5776

e-mail: funo@archi.kyoto-u.ac.jp

(Received September 9, 2001; accepted December 17,2001) built according to strict planning principles is of great significance in making a comparative study on the regional development of Hindu city planning ideas.

While the study of Cakranegara analyzed the social and spatial structure of the city, no work on the same level has yet been done on Jaipur ${ }^{6}$ to make a comparative study between the two cities. Accordingly, in this study, basic comparative data on the physical dimensions of the streets, the street system and on the distribution of the dwelling units has been collected ${ }^{7}$. During the field work a collection of 43 sheets of survey maps (city area--40 + suburban area--3) covering all the old city area of Jaipur drawn to a scale of 1/1000, and conducted by the Survey of India between the period 1925 to 1928 was procured. ${ }^{8}$ In these maps building blocks and number of floors of the buildings are delineated which can be utilized to analyze the changes during the developmental process of the town building.

In addition, religious centers, chaityas on the streets, wells and various elements are marked in the map. In an examination of selected areas of several street blocks, known as chowkri, uniformity in the location of religious centers can be clearly discerned. The paper will analyze this set of maps to study the street system and the neighborhood structure, and is the first attempt to utilize these maps in the study of the urban history of Jaipur. 


\section{The Planning of Jaipur}

\section{2-1. The Basic Structure of the city}

In general, the streets as illustrated by Fig. 1 are layed out on a grid pattern, but we see certain deviations in the northwest and southeast sector. At the northwest the hill of the Nagargarh fort was possibly the cause for

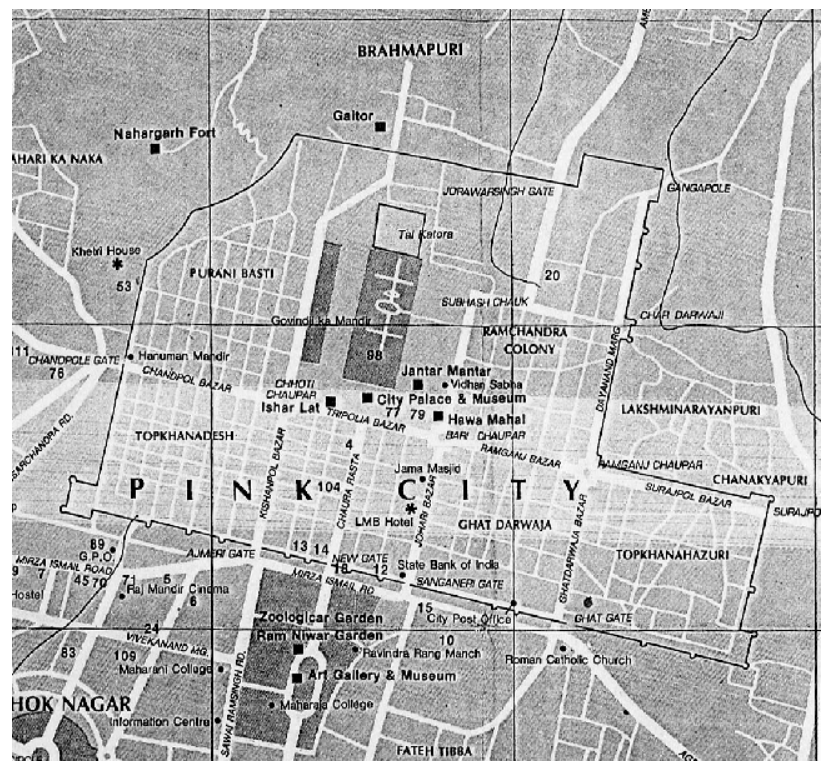

Fig. 1. The Old City of Jaipur

the incomplete grid while at the southeast a whole chowkri brakes away from the square geometry.

The central part of the city is occupied by Jantarmantar and the palace. An artificial lake known as Tal Katora is constructed to the north of the palace.

The city is known to be constituted of nine blocks but only seven divisions of blocks known as Purani Basti, Topkhanadesh, Modikhana, Visheshvarji, Ghat Darwaja, Ramchandra Colony and Topkhanahazuri can be identified. It is thought that Modikhana and Visheshvarji originally belonged to a single block, which was later divided into two by the construction of Chaura Rasta 9 . If the area occupied by the palace is considered to incorporate two blocks and the area at the north of Ramchandra Colony another block, the total number of the blocks will then be nine.

The entire city was encircled by the city wall with four gates at the south and one each in the east, west and north. If we exclude one gate in Chaura Rasta built later along with the street, there will be three gates built originally along the southern wall of the city.

A major thoroughfare running east-west deviates 15 degrees towards the north. Chandpole bazaar, Tripolia bazaar, Ramganj bazaar and Surajpole bazaar line this street connecting Chandpole (moon) gate at the west and Surajpole (sun) gate at the east. At the crossings of this street and the three major streets running northsouth, three urban squares, known as chaupar, vizChoti chaupar, Bari chaupar and Ramganj chaupar are built. Further, bazaars such as Kishanpol bazaar, Johari bazaar and Ghat darwaja bazaar line the south of each of these squares. These bazaars with shop fronts from 3.6 to $4.0 \mathrm{~m}$ and uniformly lining the streets creates a special visual apppeal to the urban street scene of Jaipur.
A large number of Hindu temples and shrines are distributed within each neighbourhood quarter. The dwellings known as haveli are built over the entire city. Initially these havelis were two storeys high, which at present, are of four to six stories high in the central area of the city.

\section{2-2. Interpretations on the Planning Concept of Jaipur}

There exists a considerable body of research literature on Jaipur. Major citable works are listed in the reference. Works on the history of the city have been referred to by A. K. Roy (1978) and J. Sarkar (1984). Official documents prepared by the Department of Home Ministry, materials in languages such as Hindi, Rajasthani, Sanskrit, Persian, and travel diaries constitute first hand references. There are also numerous reports and dictionaries to be found from the latter half of the 19 th century.

If we include ancient classical works, such as Arthasastra and Manasara ${ }^{10}$, relevant to the city planning and architecture, the bibliography will be much longer. The works of Ramraz (1834), E. B. Havell (1913), Dutt (1925), Kirk (1978), Begde (1978) may be cited as representative works. In Japan, there are works such as those of M. Konishi (1985) and K. Iizuka (1969). Following these works, T. Ohji (1990) makes an attempt to bring together the various theories regarding the city's form after A. Nilsson's interpretations (1987). B. Ghosh (1965), K. Jain (1978,1994), and N. Rajbanshi (1993) carried out research works from architecture and town planning disciplines in India.

There are no written records left by Jai Singh II and Vidyadhara. Numerous theories and interpretations have thus been put forward on the concept of the city planning of Jaipur, and to explain the form realized in practice. All these explanations have one thing in common in pointing out that the idea for the city form of Jaipur was informed by ancient Hindu cosmology.

As is well known, Manasara has given illustrations of various village settlements, towns, forts and city forms. F. B. Havell (1913) pointed out that Jaipur is modelled after the form of Prastara ${ }^{11}$ as prescribed in the classics of Vastusastras. B. B. Dutt (1925) basically agrees with his proposition. However when we compare the various aspects of the city such as the number of gates and urban blocks - the chowkri divided by major streets, Jaipur is different from the form of Prastara.

It is generally considered that the city was built in a so-called nine square form with $3 \times 3$ divisions of square blocks. Yet the entire block of Topkhanahazuri at the south-east which projects out from the grid contradicts the ideal square geometry. This anomaly is explained by stating that the block is a substitute for that part of the city at the north-west which could not be built because of the hilly terrain.

The deviation of the grid rotating clockwise by 15 degrese from the cardinal directions has also been given various interpretations. One view considers the swamp area at the north-east and the declination of the hill as factors in the orientation of the grid. ${ }^{12}$ While A. Nilson (1987) considers that the grid aligns with the axis of Leo-the zodiac sign of Jai Singh II. N. Rajbanshi 
(1993) puts forward physical interpretations suggesting that the rotation of the grid helps to create shadowy streets and facilitates the wind flow. The view that the planning of Jaipur could possibly have been influenced by European city planning ideas is also suggested, citing the publication of the city maps that include many grid pattern cities by Johann Baptista Homann in 1725 . $^{13}$

T. Ohji (1990) brings together diverging theories regarding the form of Jaipur and proposes a unified explanation. His explanations, which model the original form of the city based on the tenets of Arthasastra are persuasive. It is not that the principles of Arthasastra were applied in all its letters, but the idea behind the division pattern of the city into urban blocks - chowkri, might be considered to have been derived from the model of Prastara. T. Ohji, while supporting Nelson's explanations on the inclination of the grid, further adds that the axis created by the Suraj gate and Chandpole gate positions the Suraj temple at the focal point which also might have been the additional factor in modulating the orientation of the grid. Further, the location of the Brahmapuri quarter to the north of the palace suggests that the planning of the city was informed by the Hindu ideal of city planning.

\section{Analysis of the City Map (1925-26)}

\section{3-1. The Map Index and its Organization:}

Maps of the city are called 'Jaipur City and Environs'. Measurement is in feet, and all the sheets of the map are signed by Jos Mutti-superintendent of the Survey of India.

When Man Singh II (1922-40) took the title of Maharaja, the administration of the city began to be run by the state parliament that included the British residents. The municipal committee was reformed in 1926 and a new municipal regulation came into effect in 1929. The city map was part of the reform program on real estate taxation as well as urban development planning, and thus, is an important document recording the turning point in the administration system.

The reliability of the city map was checked by measuring the dimensions of the chowkri of Purani Basti using a wheel measure, and it verifies that the mapping was conducted with an excellent degree of survey accuracy. In addition, A. K. Roy $(1978)^{14}$ provided measurement data of 1973 , which is found to be accurately plotted in the city map.

\section{3-2. Dimensions of the Streets}

As is known, Manasara prescribed in detail the measurement systems

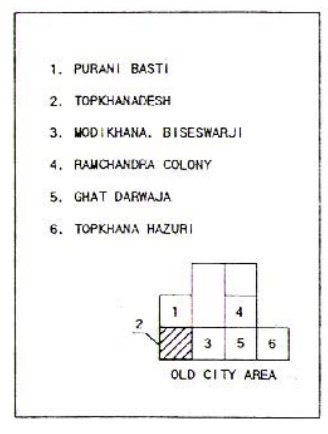

1. The numbers in the circles are the widths of the streets.

2. The dimensions at the city wall are measured from inside of the wall.

Fig. 2. Street dimensions and divisions of Topkhanadesh at the begining of its second chapter ${ }^{15}$. On the planning of towns, it is considered that 'danda' was the unit of measurement (one danda $=4$ hasta $=6$ feet approx.), and it is a common practice to use hasta (one hasta $=$ $45 \mathrm{~cm}$ approx.) as the unit of measurement in India ${ }^{16}$. Records show that the measurement unit for land was called 'bigha'. One bigha area of land is one bigha unit length in either direction. However according to E. R. K. Blenkinshop ${ }^{17}$, the regional commissioner appointed in 1924, the measurement value for bigha varies from $100 \mathrm{ft}$ to $185 \mathrm{ft}$ depending upon the place. On the other hand, the measurement unit observed in Jantar-mantar (the height at the apex is $90 \mathrm{ft}$ ) and the survey data given below indicates that feet and inches were in use by the time of the construction of Jaipur ${ }^{18}$. Since the city map was surveyed in feet, it is considered appropriate to use feet $(30.48 \mathrm{~cm})$ as the measurement unit in the following analysis of the Jaipur city map.

A field survey covering the whole city area shows that there is a considerable degree of difference in the width of the streets ${ }^{19}$. According to the survey conducted by A. K. Roy in 1973, the width of the main street is about $108 \mathrm{ft}$ ( 72 hastas) while there is no standard so used for other streets. However, a hierarchy in the street width is evident. The case of Topkhanadesh gives average widths of $33 \mathrm{~m}(28-35 \mathrm{~m})$ for the main street, and $14-17 \mathrm{~m}$ for the street next to it in the hierarchy (Fig. 2). Following this the minor streets have widths of $6.5-9 \mathrm{~m}$ and narrow lanes of $3-5 \mathrm{~m}$ thus making differences in width according to the hierarchic level of the streets.

The imperial gazetteer of India notes $111 \mathrm{ft}$ for the width of the main street and $1 / 2$ and $1 / 4$ of that for other streets $^{20}$. However, this is a record from the beginning of the 20th century and may not be taken as an evidence for the original planning and construction.

B. Ghosh (1965) gives the widths of the streets as $111 \mathrm{ft}$ (74cubits), 54ft (36 cubits) and $27 \mathrm{ft}$ (18 cubits), but the sources of his data are not clear, and the value given

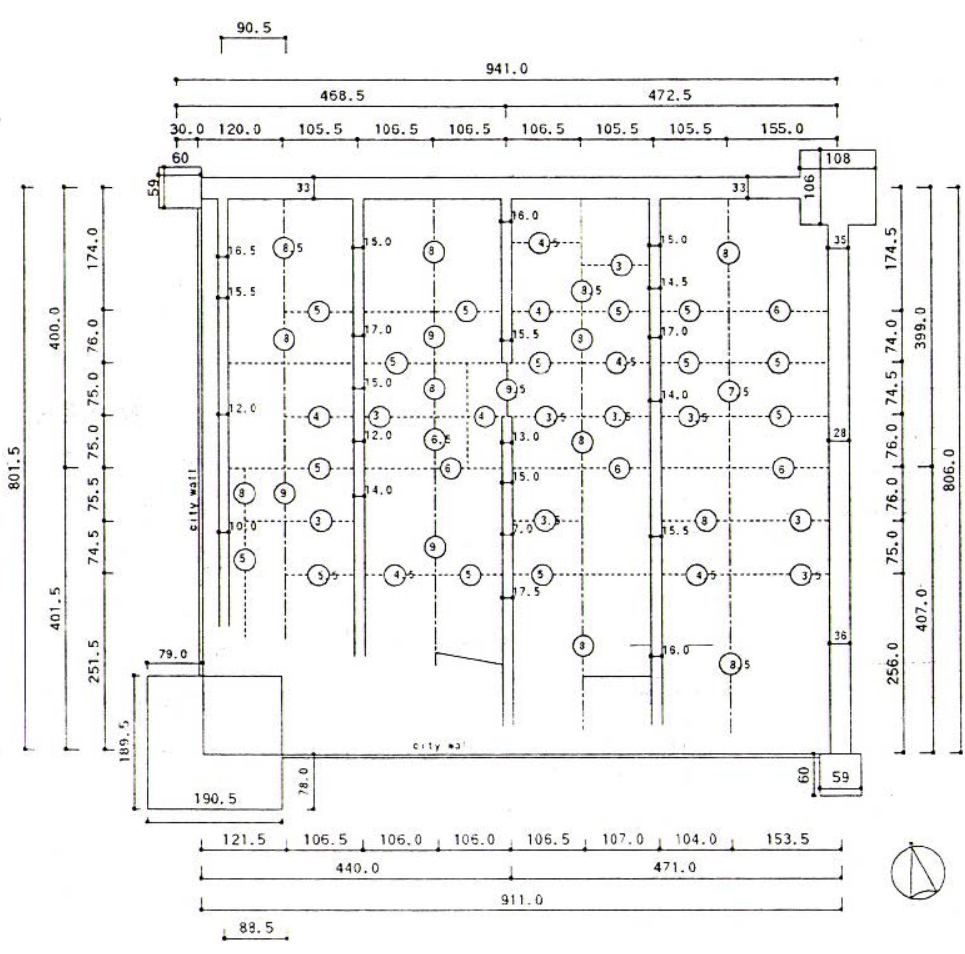


does not accord with the relationship of onehalf and one quarter of the main street. In this measurement if we consider 27 as a modular unit which is the number of houses of the lunar mansion, it then follows that feet were used as the standard measurement unit.

Regarding the measurement of the widths of the streets, the problem of the original boundary line of the street has to be resolved first since the survey data could differ according to the assumed boundary line. In the main streets shop houses with widths of $3-4 \mathrm{~m}$ and a depth of $9.0 \mathrm{~m}$ line the street to form a bazaar. There is an intervening semi-public space of 5-6ft, called a mandapa (verandah, terrace), in between the shop-house and the pedestrain walkway, and the street width differs according to whether the houses are built in this part or not. If we thus exclude this semi-public space the width of the street is about $100 \mathrm{ft}$. The addition of the verandah space 5-6ft wide on either side increases the width of the street

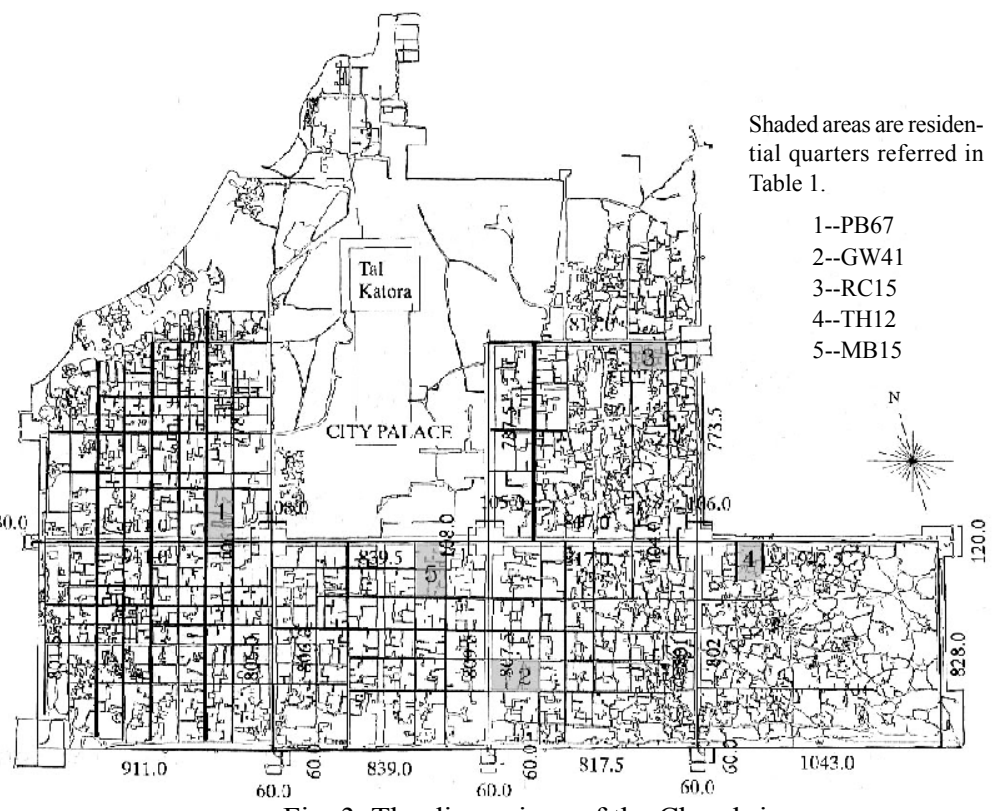

Fig. 3. The dimensions of the Chowkri to $110-112 \mathrm{ft}$. The width of $111 \mathrm{ft}$ given by the Imperial Gazetteer accords well with this dimension. One of the useful reference basis to be noted in the dimensional system is that the sizes of the city wall have dimensions in round figures. The Chandpole gate, Sanganeri gate, Ajmeri gate and Ghat gate are $200 \mathrm{ft}$ square while Suraj gate is $400 \mathrm{ft}$ square.

If we consider the basic standard size for the street width to be $100 \mathrm{ft}(30.48 \mathrm{~m})$ and derive the other standards as $50 \mathrm{ft}(15.24 \mathrm{~m}), 25 \mathrm{ft}(7.62 \mathrm{~m})$ and $12.5 \mathrm{ft}(3.8 \mathrm{~m})$, it is possible to explain the hierarchical relationship of the measured data and their distribution. The widths of the main and secondary streets, including the mandapas of $5 \mathrm{ft}$ on either side becomes $110 \mathrm{ft}(33.5 \mathrm{~m})$ and $60 \mathrm{ft}$ $(18.3 \mathrm{~m})$ and tallies with the data of the survey. It thus appears that the planning of the street width has been standardised in an extremely simple manner. Furthermore, the dimensions of the three market squareschaupar is $106-108 \mathrm{~m}$ square which indicates $350 \mathrm{ft}$ $(106.67 \mathrm{~m})$ to be the planning dimension of the squares.

\section{3-3. The Neighbourhood Quarter and the Street Pat-} tern

There is considerable discrepancy in the dimensions of blocks than is apparantly thought (Fig. 3). The dimensions measured on four sides of all the chowkri are given below:

\begin{tabular}{|c|c|c|c|c|}
\hline & north & east & south & west (m) \\
\hline Purani Basti & $(-$, & 778.0 & 911.0, & $\longrightarrow$ ) \\
\hline Topkhanadesh & (911.0, & 806.0, & 911.0, & 801.5 ) \\
\hline Modikhana & & & & \\
\hline + Visheshvarji & ( 839.5, & 809.0, & 839.0, & $806.5)$ \\
\hline Ghat Darwaja & ( 817.0, & 801.0, & 817.5 & 787.5 ) \\
\hline Ramchandra C & $y(817$ & 773.5 & 817.0, & $787.5)$ \\
\hline Topkhanahazuri & ( 942.5, & 828.0 & 1043.0, & $787.5)$ \\
\hline
\end{tabular}

Although the variation in the north-south direction of the northern blocks of the city is not clear, the width ranges from $778.0 \mathrm{~m}(2552.5 \mathrm{ft})$ to $787.5 \mathrm{~m}(2583.7 \mathrm{ft})$. In the blocks at the south, the deviation is greater to-

wards the eastern end $(828.0 \mathrm{~m})$. While in the central quarters the width ranges from $801.0 \mathrm{~m}$ to $807.5 \mathrm{~m}$. There is also irregularity in the east-west direction of the blocks with widths $911.0 \mathrm{~m}$ (2988.8ft), 839.5m (2754.3ft), $817.0 \mathrm{~m}(2680.4 \mathrm{ft})$ and $942.5 \mathrm{~m}(3092.2 \mathrm{ft})$. Among the four blocks at the south, the two blocks at the two ends are considerably larger than the two blocks at the centre. However it is notable that the length of Chandpole bazaar, measured from the centre of Chandpole gate to the centre of Choti chaupar, which is $941.0 \mathrm{~m}$, is almost the same as that of Surajpole bazaar at the east. The width between Choti chaupar and Ajmeri gate and between Bari chaupar and Sanganeri gate are respectively $836.1 \mathrm{~m}$ and $837.5 \mathrm{~m}$. Thus the Chowkri (Modikhana + Visheshvarji) at the south of the palace can be considered as a square. The other remaining blocks are neither square nor of a similar size.

There are irregularities also in the street grid. In particular, the internal streets within the whole block of Topkhanahazuri, where the Muslims are dominant, are irregular. It is notable that more irregularities are observed as one goes farther out of the Palace.

Internal divisions of Topkhanadesh are derived first by dividing the chowkri into four blocks by the secondary streets of $50 \mathrm{ft}$ in width running north-south. Each of these blocks is then divided into two sectors by the minor streets running parallel to it, thus giving eight longitudinal blocks within the chowkri. This pattern is also to be observed in the district of Purani basti. These blocks are further divided by the street lanes running east-west that form the final layer of the grid system. While there are discontinuities at certain sections of some of these street lanes, six are distinct in the pattern of the street grid. Considering that the blocks at the south are almost twice as large as the average size of other blocks, an additional east-west street lane may be assumed within this block of the chowkri. This reconstruction shows that the chowkri was planned constituting 8 $\mathrm{x} 8$ blocks.

The width of the blocks in the east-west direction are 
fairly consistent ranging from 104 to $107 \mathrm{~m}$ (350ft approx.). This division between the centre of Chhoti chaupar and Chandpole gate which is $941.0 \mathrm{~m}$ (3087.3ft) in length can be deduced from $500 \mathrm{ft}$ $+350 \mathrm{ft} \times 6+500 \mathrm{ft}=$ $3,100 \mathrm{ft}$. In the northsouth direction, if the blocks at the north and south are excluded the

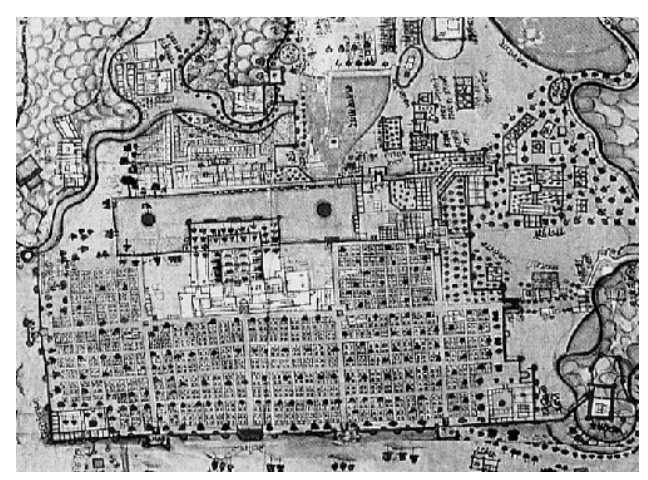

Fig. 4. The City map, No. 16

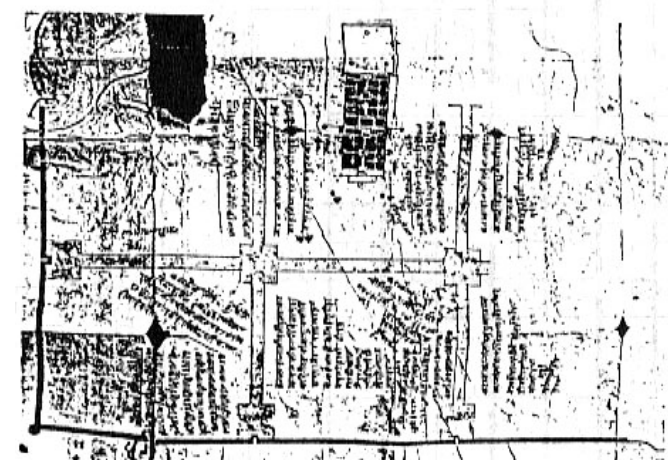

Fig. 5. The map indexed as No. L. S./14 width of the central blocks is between 74 to $76.5 \mathrm{~m}(250 \mathrm{ft}$ approx). Thus, excluding the peripheral blocks of the chowkri, the basic standard dimension of the block divisions of the chowkri is $350 \mathrm{ft} \times 250 \mathrm{ft}$.

In the case of Purani Basti, the northwestern sector is segmented and the divisions are not as clear as those of Topkhanadesh. Although the pattern of divisions leading to $8 \times 8$ blocks may be assumed, the rationale behind the varying widths of the blocks between the eastwest streets must be given consideration. This might well be the result of the planning reality in the block divisions of Purani basti.

The regularity observed in the above two chowkri are more apparent when compared with other chowkri of the city. In particular, the secondary streets in other areas are much narrower than $50 \mathrm{ft}$. Considering that Chaura rasta was a later development and excluding the north-south street of Ramchandra colony at the east of the palace, all the streets are less than $25 \mathrm{ft}$ wide, that is less than half of the standard dimension. It can be said that enforcement of the planning principle was severely weakened in the development process of the city.

The chowkri of Modikhana-Visheshvarji, Ghat darwaja and Ramchandra colony all are divided into six blocks by the north-south streets. In particular this system of division is distinct in Modikhana-Visheshvarji, which is divided into planned units of $6 \times 6$ blocks. When the expansion of the chaupar $(350 \mathrm{ft})$ at both end corners of the chowkri is deduced from the width of the chowkri, the width of the block divisions of Modikhaana-Visheshvarji are $384.4 \mathrm{ft}, 395.3 \mathrm{ft}, 428.1 \mathrm{ft}$, $390.4 \mathrm{ft}$ and $356.5 \mathrm{ft}$ giving approximately $400 \mathrm{ft}$ as the basic module for the block divisions. The division of the length of the chowkri between the chaupar $(829.5$ $\mathrm{m}$, i. e., $2754 \mathrm{ft} \mathrm{c} / \mathrm{c})$ might have been derived as $175 \mathrm{ft}+$ $400 \mathrm{ft} \times 6+175 \mathrm{ft}=2750 \mathrm{ft}$. The block widths in the north-south direction divided by the east-west streets however are not uniform thus resulting in various size of blocks in the chowkri. A map drawn in the latter half of 18 th century shows chowkris divided into $8 \times 8$ blocks (Fig. 4). But in reality the city differs from this map to a great extent.

According to the preceding analysis, the degree of regularity of the chowkri may be drawn in the following order: 1. Topkhanadesh, 2. Purani basti, 3. Modikhana-Visheshvarji, 4. Ghat darwaja, 5. Ramchandra colony and 6. Topkhanahazuri. It then may be assumed that the above sequence is also the order of

the sequence of the development of Jaipur. The district of Topkhanadesh, Purani basti and then ModikhanaVisheshvarji are the planned units at the initial stage. The reading of the street and block dimensions indicate that these three blocks and the royal palace constituted the originally planned area of the city. A map indexed as No. L. S./14 (Fig. 5) that belonged to the palace showing four chowkris strengthens this conclusion regarding the developmental sequence of the city. If we consider that there were four blocks at the initial stage, the form of the city will then resemble the ideal form of Prastara.

\section{The Dwelling Units of Jaipur 4-1 Haveli}

A glance at the city map shows the dwellings of the city arranged in a series of big and small open courtyards. The larger residences have a number of courts in addition to the main central courtyard. These residences are called haveli .

Jaipur, geographically located at the entrance of the Thar desert has a hot and arid climate. Accordingly, devices to cast shadows in the summer is more important than the requirement of sunshine. The dimensions of the central court and its height are determined in such
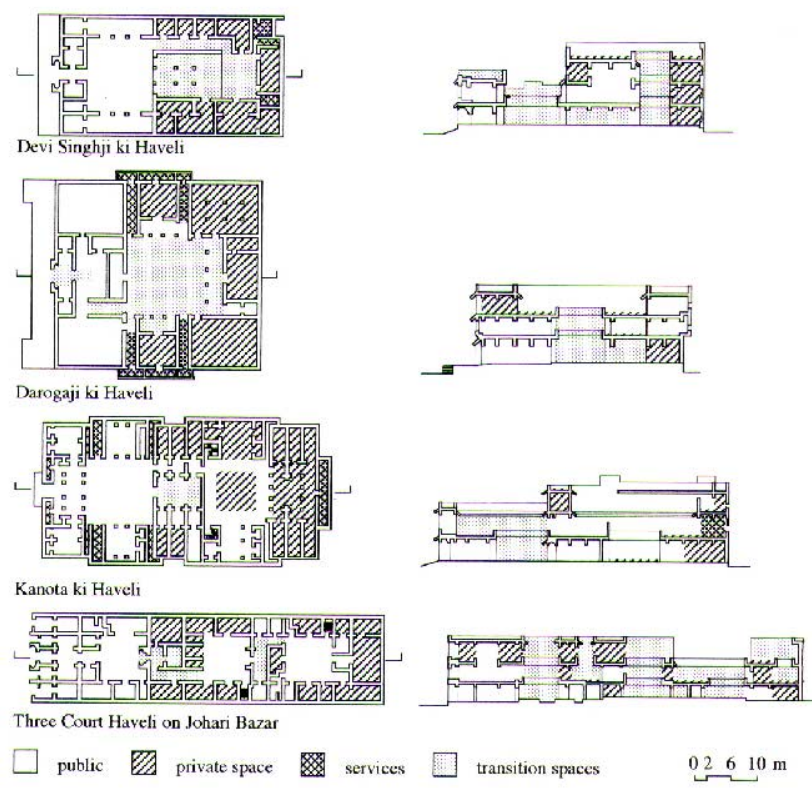

Fig. 6. Typical examples of haveli 


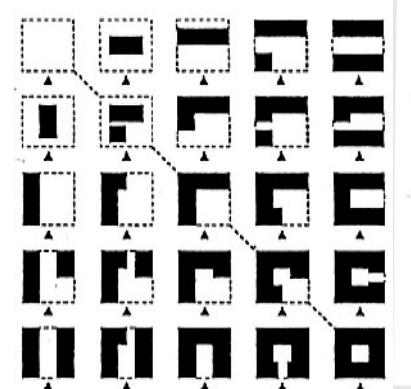

Fig. 7. The basic units of residential building types

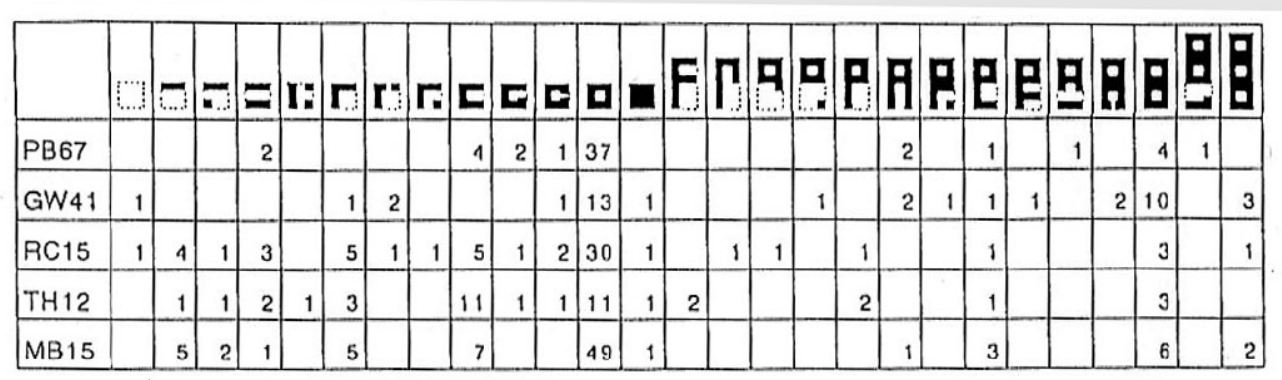

Table 1. Distribution patterns of various residential building types a manner that the courtyard will be in shadow in the summer afternoons. Also, higher parapet walls are built along the west to block the glare from west. Further, the central court functions as a cooling reservoir on summer nights and the roof is used at night for the cooling breeze. 'Chatris' and 'chajjas'(open pavillions) also serve the purpose of sunshade.

\section{4-2 Types of Residential Buildings}

It can be seen that the courtyard form constitutes the basic residential type in the settlement quarter of Jaipur city. The typical examples are as illustrated in Fig. $6^{21}$. Residential types may be classified according to the number of courts which makes it easier to understand the order of the house plan. The reading of the city map shows additional types of house form. Especially in the areas with low density, one finds house forms in I, L and $U$ shapes .

The relationship of various house types and the courtyard form and their relationship may be represented by the model shown in Fig. 7. This model expresses the evolution of the house from its initial phase when an I shape dwelling block is built to the final stage when dwelling blocks are gradually built to enclose a courtyard. The block GW41 at the west of Ghatdarwaja (Fig. 8, Cf. Fig. 3) presents the case example in this analysis showing the forms of house types. Table 1 gives the distribution of these house types in a random sampling of residential neighbourhoods of various chowkris.

Although the courtyard form of the house type is readily apparent as the feature of the residential neighbourhood, the houses with completed courts as shown in Table 1 account for about half (49.8\%) of the total number of dwelling types. While houses with a U shape occupy $9.6 \%$, the multiple courtyard types of houses make up $9.3 \%$ of the total sampling.

However, the variation in the sizes of the residences is considerable. For instance, the houses of Topkhanadesh

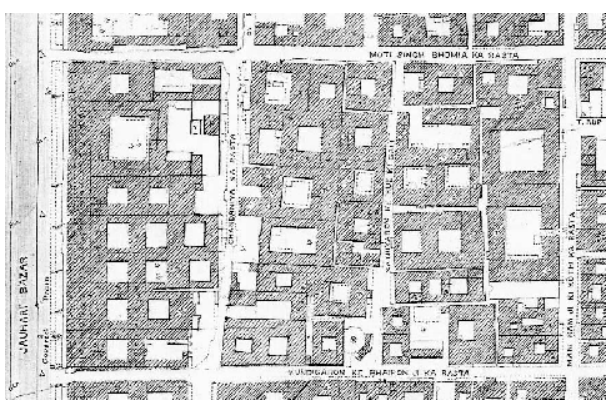

Fig. 8. Residential quarters of Ghatdarwaja range from $24 \mathrm{sqm}$. to $1,050 \mathrm{sqm}$. Fig. 9 shows spatial distribution of the houses with frontage greater than 20 $\mathrm{m}$. The size of the havelis in the neighbourhoods of the palace are larger while such havelis in the periphery are few in number. The districts of Puranibasti and Topkhanadesh at the western part of the city which were built at the initial stage of planning have not necessarily a greater number of large havelis. The social planning principle enumerated in Arthasastra that Brahman will live in the north, Kshyatriyas in the east, Vaisyas in the south and accordingly Sudras, the class on the lowest rung of society, in the west may be considered to have concrete manifestation in the city of Jaipur. The internal divisions within the chowkri of Puranibasti and Topkhanadesh in the western part of the city are also more in number resulting in smaller residential quarters. The type of haveli with a series of three courtyards is concentrated along Johari bazaar at the east of the chowkri. This is because of the increased depth of the plot available in the given size of the residential district.

A detail reading of the city map shows that there are areas with regularity in the distribution of the dwelling size. These are areas with planned development in the city. As an administrative centre, a large number of officials and military personnel lived in the city of Jaipur. Renumeration to the officials of the government was given in the form of land and the officers holding such land were called jagirdar ${ }^{22}$. In the latter half of the 18 th century, houses were built for jagirdars by reimbursing part of their annual income to the state treasury. Many residences were thus built in the districts of the city

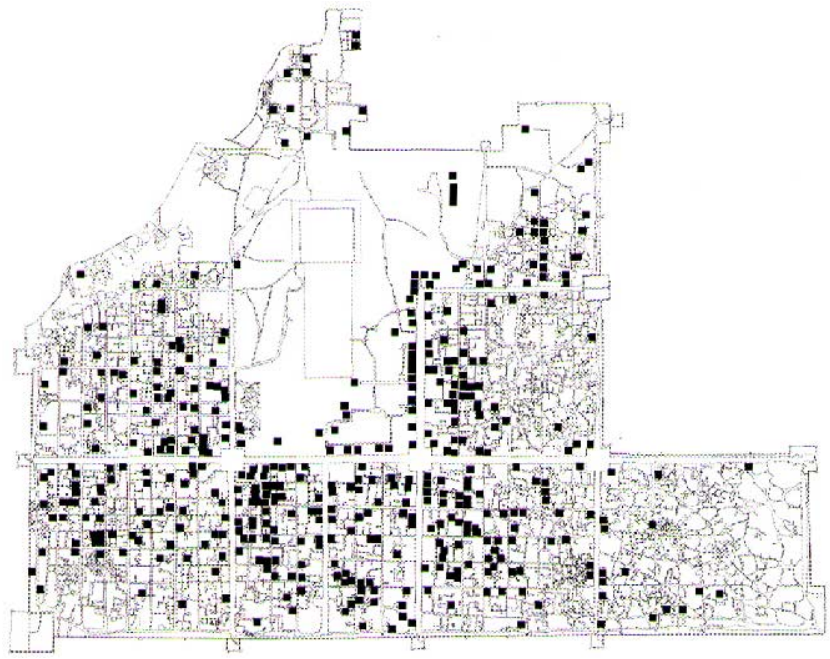

Fig. 9. Distribution of dwellings with frontages greater than $20 \mathrm{~m}$ 
except Topkhanadesh. This process of planned housing development led by Maharaja formed the guidelines in the urban development of Jaipur.

\section{The Neighbourhood Structure \\ 5-1 The Size of the Neighbourhood}

The residential blocks vary according to each chowkri. Although the average size of the residential blocks of all chowkri taken together is 1.42 ha (east-west $110.6 \mathrm{~m}$, north - south $125.4 \mathrm{~m}$ ), the variation in the size of individual quarters is considerable. However, in Topkhanadesh, where the grid pattern is most regular, three types of residential quarters can be identified which have been determinant in the size of each quarter of the chowkri. Quarters with east-west dimensions ranging from $95-100 \mathrm{~m}$ are $54(42.9 \%)$, those from $110-115 \mathrm{~m}$ are $12(9.5 \%)$ and those from $130-135 \mathrm{~m}$ are $10(7.9 \%)$. While those at the north-south with dimensions ranging from $65-75 \mathrm{~m}$ are $40(31 \%)$, those from $105-115 \mathrm{~m}$ are $12(9.5 \%)$ and those from $145-155 \mathrm{~m}$ and $205-215 \mathrm{~m}$ are each $10(7.9 \%)$. It is thought that the initial planning dimensions of the city are reflected in the dimensions of these quarters.

\section{5-2 Marga and Rasta}

In Jaipur, the neighbourhood residential quarter is known as 'rasta' or 'marga'. 'Rasta' is street in the Hindi language while it is 'marga' in sanskrit. The residential districts of Jaipur have streets on two sides. The houses facing the same street constitute one rasta (marga). However, along the length of a single street, the rasta denotes only a segment and the name varies for different segments of the street. For instance, the name of the street at the west of Johari bazaar (the eastern most street of Vishesvarji chowkri) changes as one goes from north to south such as-Hanumanji ka rasta, Kotyahwalon ka rasta and Bara gangaron ka rasta respectively. The name changes with the crossing of the street by the east-west streets. Thus the block surrounded by streets on four sides constitutes a unit. Rastas are named after popular Hindu deities, or the occupation of the community, or after some famous personality.

It has been reported that the size of residential quarters of Vidyadhar nagar ${ }^{23}$ range from $160 \mathrm{~m} \times 160 \mathrm{~m}$ to $110 \mathrm{~m} \times 110 \mathrm{~m}$; the marga is composed of $40-50$ households and the residents of marga belong to the same caste or subcaste and practise the same occupation, and that the marga as a community unit has been conducive to the social and cultural activity of the residents.

The above statement on the size of the community quarters is not correct. The caste corresponds to occupation and a caste grouping is also an autonomous community. A caste is an endogamic community while the subcaste practises exogamy. The marga therefore acts like a huge clan house with strong binding force among its community members. The marga is a community unit based on the caste structure. Unlike the bazaars along the main streets, the shops within the chowkri are run by the respective marga community residents. The shops and the workshops indicate the caste of the owner to a certain extent. It appears that there is a tendency of like occupations grouping in the same marga.
With the process of modernization, the characteristics of marga associated with caste community is breaking down. On the other hand the trend of sanskritization ${ }^{24}$ has also increased the cohesiveness of the caste community.

The 1881 census provided data on the number of mohallas (marga) in each chowkri. The total population within the city wall in 1881 when the all India census began was 125,785 . All the chowkris of Jaipur had already been developed and Sarhad at the north of the palace was also beginning to be settled. Except for the new street Chaura rasta which was constructed in an unbuilt area, there was not much change in the city after the death of Ram Singh in 1880.

\section{5-3 Galli and Gher}

On the city map, one finds numerous streets within the residential quarters noted as 'galli'. A residential quarter is made up of several lanes which are called 'galli' in Hindi. Most of these gallies are in the form of cul-de-sacs. As with 'marga', 'galli' is a street and also represents a residential unit of a lower order. The width of a galli is usually norrower than the width of the marga. The houses having their entrance in the same lane belong to one residential unit and are known after the name of that lane. The residential quarter surrounded by marga is thus further divided into lane units, and although the blocks of the residential quarter are similar in their rectangular shape they have variagated forms of residential clusters depending upon the number of divisions into lanes and their orientation.

Fig. 10 shows the organization of residential units in a quarter at the north west of Vishesvorji illustrating various forms of galli and their relation to rasta. It is seen that the pattern of the division of the residential quarter into residential units by gallis is not of the same type but varies according to the needs of the individual units.

On the city map there are also spaces noted as 'gher' within the residential quarters, for instance, Banwalon ka Gate chaura rasta has been noted as "Shree Jhankinath Ji ka Gher'. 'Gher' is derived from 'ghar' meaning a house including its compound. It is a space usually at the end of a lane in the form of an open court. Dwellings, shops and workshops are built around the gher making a residential unit. There are many other spaces resembling gher. Chowk is one of them, which is an open space similar

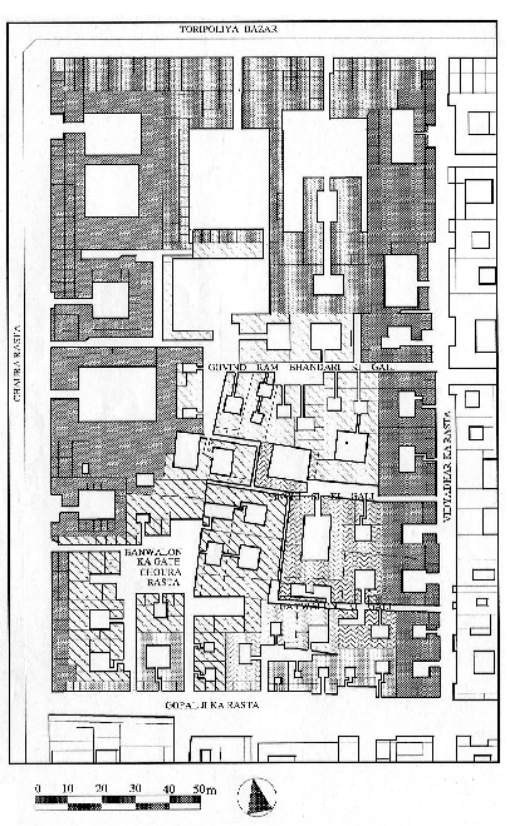

Fig. 10. A Quarter at the northwest section of Vishesvorji 
in form to the courtyard. Chowk is originally derived from the word meaning 'four cornered', and the courtyard of a residence is called 'chowk'. Various other toponyms such as chowkri and chaupar are thus derivatives of chowk. The courts known as gher are found to be more concentrated in the eastern sector of the city.

\section{Conclusion}

The above analysis shows that in practice Jaipur is not necessarily a city with a strict grid pattern street system. This paper is the first to present such an analysis on the dimensional system of the city. The major characteristics to highlight the argument concerning the planning concept of Jaipur are as follows:

(1). The urban blocks - chowkri, formed by the main streets are not of uniform size. However, the three chaupars are of the same size ( $350 \mathrm{ft}$ square); thus their present form derives from the planned execution of that period. It is not yet clear whether the ideal planning concept of $3 \times 3=9$ square has been employed in Jaipur, but the importance of the east-west central street is clear. This street was a long established route from olden times and runs parallel to the ridge of the hill at the north. In addition, the fact that it is an axis to the Suraj temple in the east must have led to the east-west street as the first factor in making the planning decision.

(2). A distinct hierarchy exists with respect to the street system as shown by their dimensions, viz $-100 \mathrm{ft}$ $(30.48 \mathrm{~m}), 50 \mathrm{ft}(15.24 \mathrm{~m}), 25 \mathrm{ft}(7.62 \mathrm{~m})$ and $12.5 \mathrm{ft}$ $(3.91 \mathrm{~m})$. The organiztion of the residential blocks was arranged based on this concept. But this principle gradually weakens in the latter stage of development.

(3) Analysis of the street pattern and block dimensions shows that in the evolution of Jaipur, Topkhanadesh, Purani basti and then ModikhanaVisheshvarji and the royal palace constituted the originally planned area of the city.

(4.) Topkhanadesh is divided into a number of $8 \times 8=$ 64 uniformly planned blocks. This subscribes to the ancient planning principles of India. However Purani basti, Modikhana + Visheshvarji employ a different pattern in the division of blocks. The idea of the Prastara model of city form, in which the size of the blocks could vary according to the caste can not be negated. If we consider that there were four blocks at the initial stage, the form of the city will then resemble that ideal form of Prastara.

(5) Irregularities in the street pattern become more apparent as one goes farther from the centre towards the periphery of the city. The quarters with irregular street pattern concide with the distribution of the mosques. This might have been due to the influence on the settlements by the Muslim communities.

(6) The basic unit of the residential form constituting the city of Jaipur are houses with internal courtyards known as haveli. The size of the havelis vary but their clusters in the residential units make up a chowkri,the residential district.

(7) Large havelis are distributed in the immediate neighbourhoods of the palace while havelis of smaller scale are to be found at the west. This also reflects the distribution pattern of the communities according to their status in the social hierarchy. It also shows the planned development intended to settle the jagirdars, which has been a decisive factor in building a unified townscape. (8) The chowkri is divided into rectangular blocks of residential quarters by streets known as rasta or marga. The marga with clusters of residential units on either side is also a social and spatial unit. Initially, residents living in the same marga belonged to the same caste or subcaste and profession. Marga were founded on the basis of caste and thus formed a veritable community unit.

(9) The residential quarter is further divided by gallis which are also residential units. There are no regularities in the form of gallis as in rasta. The grid pattern might be discernable but the contingencies of diverse factors have been important in creating the various forms and size of gallis.

\section{Endnotes}

1. Funo Shuji, Wakita Hisano, Aoi Akihito, Yamamoto Naohiko, Norio Maki: 'Street Pattern and Block System of Cakranegara City, Lombok, Indonesia, Part 1', JIA Planning Research Paper Series No. 491, Jan 1997. Shuji Funo, 'Space Formation of Cakranegara, Lombok', forthcoming as one chapter of "Indonesian Cities", P. Nas, ed., (Leiden University).

2. Jaipur is named after Jai Singh, which formally was called Sawai Jaipur. It has been simply known as Jaipur (Jypore, Jeipor). The city was also known as Jainagar from the end of the 18th century. Pink city is its other name for its color of walls along the street. It is said to have been decided during the period of Ram Singh's rule (1835-1880).

3. Jai Singh studied ancient literature and enquired on the traditional knowledge of medicine as well as other various sciences. He was particularly versed in mathematics and astronomy and built astronomical observatories known as Jantar-mantar not only in Jaipur but also in other cities-Shahajahanbad, Mathura, Ujjain, and Varanasi. He was a Vaisnavite of the Hindu religious denomination. Thus the planning of Jaipur is much influenced by Jai Singh's religious beliefs and his scientific ideas of the time.

4. The family name of Vidyadhar is Cckravarti, also is claimed to be Bhattachararya.

Vidyadhar was appointed as minister for construction in 1729. It is thought that Vidyadhar's involvement in the planning of the city came after the construction of the city forts in 1726 . Thereafter, any new construction plan in the city was first submitted to Vidyadhar for his permission. Thus the unified townscape of the city owes a great deal to Vidyadhar's contribution.

5. The foundation stone was laid on Nov 29, 1723. Records show that the construction of the observatory began in 1718 . The Jainivas garden area was constructed before the observatory and in 1729 the city wall and city were completed.

6. In Cakranegara, the hierarchy of the street pattern is in three levels: marga sanga (the east-west and north south central cross), marga dasa (main roads), and marga (minor roads). Urban district blocks are formed by marga dasa, and each block is then divided into four sub-blocks by three streets running north-south. Each sub-block is further divided into 10 units back to back along these streets, resulting in 20 house plots known as pekarangan. The cluster of these 20 plots in between the marga are also known as marga. Two such marga clusters form one kriang and two kriang make one karang.

7. The survey was conducted between March 10-Apr 2, 1994 (Funo Shuji, Shu Yamane, Aoi Tetsuto, Hitoshi Ara) and between Sep 19-Oct 3, 1996 (Funo Shuji, Yamamoto Naohiko, Numata Norihisa, Nagamura Hidetoshi, Lanshiang Hwang).

8. The maps were procured from the Jaipur Development Authority that 
holds the original sets of City Maps.

9. During the reign of Ram Singh (1835-1880) Chaura rasta was constructed as one major street from the Tripolia gate of the palace to the south and a New gate was built towards Ram nivas.

10. The Silpasastra is a term that collectively denotes the Sanskrit literature on the art of city planning, architecture, art and sculpture. The most complete work on Silpasastra is Manasara while other works are Mayamata, Casyapa, Vayghanasa, Schaladhicara, Viswacarmiya, Sanatkumar, etc.

11. According to P. K. Acharya (ref. 4), a Prastara plan has the following properties: (1) it is square or rectangular in form; (2) it is suitable to Kshetriya and Vaisya; (3) it is to be divided into paramsamyika-81 blocks, chandita -64 blocks, sthandila -49 blocks; (4) there will be an intramural road called paisacha with pedestrain paths on either side encircling the city, and with the streets connecting to this road dividing the city into four blocks is called pechaka, while those dividing the city into nine and 25 are called pitha and Mahapitha; (5) the individual blocks will be further divided by a number of streets crossing the east-west and north-south directions.

12. A. K. Roy: Architectures: the Dream and the Plan, Marg xxx-4.

13. See ref. 20. Amannath considers that the city is very much similar to Christian-Erlang. Although the influence of Europe can not be negated, it is perhaps difficult to entirely negate the influence of Hindu cosmology on a city constructed in 1725 .

14. A. K. Roy [ref. 1, pp. 46-47] has provided measurement data of 14 points: 1 . The wall to wall width of the Johari bazaar street is $108 \mathrm{ft}$; veranda to veranda $92 \mathrm{ft} ; 2$. width of Haldion ka Rasta $41 \mathrm{ft} ; \ldots . . ; 13$. the street in front of Hawamahal $108 \mathrm{ft}$.

15. The width of the thumb is one angula and 12 angula is one vitasti. two vitasti is one small cubit called kishku. One angula more in a kishku is one prajapatya. It is also of significance that one angula more to the prajapatya or 26 angula is called dhanurmusti and 27 angula is dhanurgraha. four times dhanurmusti equals to one danda and eight danda is one rajju. Dhanurmusti is approx $45 \mathrm{~cm}$ and one danda is $1.8 \mathrm{~m}=6 \mathrm{ft}$. 16. In Bali and various other places in Indonesia, 'asta' is a common measure and in particular is employed in building measurements.

17. E. R. K. Blekinshop, Note on Settlement Programme, Jaipur, 1924.

18. Feet and inches are considered to have come into use along with British rule. A British architect was employed in the design of the palace where the measurements are in feet and inches.

19. Measured by $0.5 \mathrm{~m}(50 \mathrm{~cm})$ unit.

20. Imperial Gazetteer of India (24 volumes), Oxford, 1908. East India Gazetter (2 volumes), London, 1828.

21. Sanskriti, Ramat, "Architecture of the walled city of Jaipur, Govt. College of Architecture, Lucknow, 1993.

22. Ref. 1, pp 58-59.

23. Ref. 16.

24. The process by which members of the lower cast elevate to higher rank in the hierarchy has been termed; 'Sanskritization'. On the other hand the political organizations rallying the interests of the caste members has also been a force in binding the community.

\section{References}

1) Roy, Ashim Kumar (1978): The History of the Jaipur City, Manohar, New Delhi.

2) Sarkar, J. (1984): A History of Jaipur, Delhi.

3) Kautilya: Arthasastra: L. N. Rangarajan, Penguin Books, 1992: Katsuhiko, Uemura (1984) Tr., [Jitsuriron]. Iwanami Bunko.

4) Acharya, P. K. (1934): Architecture of Manasara Vol I-V, Oxford University Press.

5) Dagens, Bruno (1994): Mayamatam Treatise on Housing, Architecture and Iconography Vol. I-II, Indira Gandhi National Centre for the Arts, New Delhi.
6) Raz, Ram (1834): Essay on the Architecture of Hindus, London.

7) Havell, E. B. (1913, 1927 (2nd Ed.): Indian Architecture, John Murray, London.

8) Dutt, B. B. (1925): Planning in Ancient India, Calcutta \& Simla.

9) Kirk, W. (1978): Town and Country Planning in Ancient India according to Kautilya's Arthasastra, Scottish Geographical Magazine, 94.

10) Begde, P. V. (1978): Ancient and Medieval Town Planning in India, Sagar Publications, New Delhi.

11) Masakatsu, Konishi (1985): Historical City of India: The Plan of Jaipur and its characteristics, Geographical Archaeology Lecture Series, Vol 3 [Historical Cities], Fujioka Kenjiro ed., Gakuseisya.

12) Iizuka, Kiyo (1969): The Study of Urban Morphology-Cultural Change and the City Forms of India, SD. Periodical supplement, Nov.

13) Jain, K. (1978): Morphostructure of Planned City Jaipur, A+U Aug.

14) Jain, K. and Jain, M. (1994): Indian City in the Arid West, AADI Centre, India.

15) Upadhyaya, S. B. (1992): Urban Planning, Printwell, Jaipur, India.

16) JDA (1994): Vidyadhar Nagar, Jaipur.

17) Rajbanshi, N. (1993): An enquiry into the Science of Traditional Architecture - A Case Study of Jaipur, Indisan Institute of Technology, Powai, Bombay.

18) Nilsson, A. (1987): Jaipur in the Sign of Leo, Magasin Tessin.

19) Ohji, T. (1990): The "Ideal" Hindu City of Ancient India as Described in the Arthasastra and the Urban Planning of Jaipur, East Asian Cultural Studies, Vol xxix, Nos 1-4, Mar.

20) Nath, Aman (1993): Jaipur, India Book House Pvt Ltd.

21) Ghosh, Bijit (1965): The Palace Complex of Jaipur, "Urban and Rural Planning Thought", Vol VIII, No. 3-4, School of Planning and Architecture, New Delhi. 